\title{
GAMBARAN PENGETAHUAN TENTANG KONTRASEPSI PADA AKSEPTOR KONTRASEPSI WANITA DI PUSKESMAS WILAYAH KOTA PEKANBARU INDONESIA
}

(DESCRIPTION OF KNOWLEDGE ABOUT CONTRACEPTION OF WOMEN

\section{CONTRACEPTION ACCEPTORS IN THE PUSKESMAS REGION OF PEKANBARU CITY INDONESIA)}

\author{
$\underline{\text { Lasiah Susanti }}^{1 *}{ }_{2}$ Ratih Ayuningtiyas $^{1}$, Sonia Mutiara Fadilah ${ }^{1}$ \\ ${ }^{1}$ Program Studi Pendidikan Dokter, Fakultas Kedokteran dan Ilmu Kesehatan, \\ Universitas Abdurrab Pekanbaru, Riau, Indonesia \\ Email korespondensi : lasiah.susanti@univrab.ac.id
}

\begin{abstract}
ABSTRAK
Pengguna Keluarga Berencana (KB) ditahun 2018 tercatat meningkat dibanding tahun 2017, namun Provinsi Riau masih menjadi provinsi kedelapan dengan cakupan pengguna aktif yang rendah yaitu 52,28\% dari total Pasangan Usia Subur (PUS) pada tahun 2018. Cara penggunaan kontrasepsi yang umum digunakan di Indonesia, yaitu metode kontrasepsi dengan cara modern seperti sterilisasi, pil, Alat Kontrasepsi Dalam Rahim (AKDR), suntik, implan, kondom, dan Metode Amenorea Laktasi (MAL), sedangkan metode kontrasepsi dengan cara tradisional, yaitu seperti pantang berkala dan senggama terputus. Metode kontrasepsi modern jangka pendek seperti pil dan suntik menjadi pilihan yang dominan digunakan dibandingkan dengan metode kontrasepsi modern jangka panjang seperti AKDR dan Implan. Salah satu penyebab itu dikarenakan masih rendahnya pengetahuan masyarakat tentang kontrasepsi dan keterbatasan jumlah tenaga kesehatan serta sarana kesehatan yang ada. Penelitian ini bertujuan mengetahui gambaran pengetahuan tentang metode kontrasepsi pada akseptor kontrasepsi wanita di Puskesmas wilayah Kota Pekanbaru. Penelitian menggunakan desain studi deskriptif observasional, dengan rancangan cross sectional, dilakukan pada 12 Puskesmas di Kota Pekanbaru. Pengambilan sampel dilakukan dengan teknik stratified random sampling dengan besar sampel 400 orang. Hasil dari 400 responden didapatkan 392 responden (98\%) memiliki pengetahuan kategori kurang, 8 responden $(2 \%)$ memiliki pengetahuan kategori cukup, tidak ada responden yang memiliki pengetahuan kategori baik tentang kontrasepsi. Hampir seluruh responden memiliki tingkat pengetahuan kategori kurang tentang 11 metode kontrasepsi.
\end{abstract}

Kata Kunci: akseptor KB wanita, kontrasepsi, pengetahuan

\section{ABSTRACT}

There is an increase in family planning users in 2018 compared to 2017, but Riau Province is number eighth province with a low active contraceptive use, which is 52,28\% of the number of fertile age couples in 2018. Sterilization, pills, Intra Uterine Device (IUD), injection, implants, 
Susanti, L : Gambaran Pengetahuan Tentang Kontrasepsi...

condoms, are the most modern contraceptive methods being used while periodic abstinence and coitus interuptus are traditional methods of contraceptive that being used mostly. Modern shortterm contraceptive methods like pills and injections still be majority choices to be used compared to modern long-term contraceptive methods like IUD and implants, the reason is due to the lack of knowledge about contraceptive methods and lack of health workers and supporting health facilities. This research purpose is to find out the description of knowledge about contraceptive methods among women's contraceptive acceptors at primary health centers in the City of Pekanbaru. Research methods using descriptive observational study design, with a cross sectional study design. This research was conducted at 12 health centers in the City of Pekanbaru. The sampling technique is done by stratified random sampling with a sample size of 400 people. Data obtained is analyse for frequency and distribution .The results showed that 392 respondents (98\%) had low category knowledge, 8 respondents (2\%) had a middle category knowledge and none of the respondents had good category knowledge about contraception. The conclusion of the study shows that almost all respondents have a low level of knowledge about 11 contraceptive methods.

Keywords: contraception, knowledge, women family planning acceptor

\section{PENDAHULUAN}

Program KB di Indonesia pertama kali ditetapkan menjadi program pemerintah bersamaan dengan berdirinya Badan Koordinasi Keluarga Berencana Nasional $(\mathrm{BKKBN})$. Program KB ini selanjutnya dijadikan sebagai salah satu cara untuk menurunkan pertumbuhan penduduk serta meningkatkan kesehatan ibu dan anak. ${ }^{1}$ Data di Indonesia menunjukkan 63,22\% dari PUS tercatat menggunakan $\mathrm{KB}$ secara aktif pada tahun 2017, dan mengalami peningkatan menjadi 63,27\%. Sampai saat ini, Provinsi Riau masih menjadi provinsi kedelapan dengan cakupan KB aktif yang rendah, yaitu 52,28\% dari total PUS pada tahun 2018. ${ }^{2,3}$ Permasalahan program KB lainnya ialah disparitas pengguna metode kontrasepsi jangka panjang (MKJP) dan non MKJP yang terus meningkat, hingga tiga kali lipat selama periode tahun 1991-2012. Data terakhir pada Profil Kesehatan Indonesia tahun 2018 masih menunjukkan angka sama, yaitu $4,5 .^{3}$ Padahal banyaknya pengguna non MKJP menunjukkan tingginya kemungkinan putus penggunaan kontrasepsi/drop out, yang secara bersamaan menggambarkan rendahnya kontinuitas penggunaan kontrasepsi. ${ }^{3}$

Tercatat mayoritas PUS menggunakan kontrasepsi modern di Kota Pekanbaru $(79,33 \%)$ dengan rincian menggunakan metode jangka pendek yaitu KB suntik $(62,71 \%)$ dan pil $(16,62 \%)$ sedangkan $15,42 \%$ lainnya menggunakan modern jangka panjang yaitu implan $(6,18 \%)$ dan AKDR (9,24\%). Data juga menunjukkan, jumlah pengguna metode jangka panjang pada tahun 2018 yaitu 17,8\%, masih jauh dari target 22,3\%. Padahal, metode KB 
Susanti, L : Gambaran Pengetahuan Tentang Kontrasepsi...

modern jangka pendek seperti $\mathrm{KB}$ suntik dan pil memiliki tingkat efektivitas yang lebih rendah dibandingkan metode $\mathrm{KB}$ modern lainnya. Hal tersebut dapat disebabkan masih rendahnya pengetahuan masyarakat tentang metode kontrasepsi dan keterbatasan jumlah tenaga kesehatan serta sarana kesehatan yang ada. , $3,4^{2}$

Pengetahuan dan sikap adalah dua hal yang membentuk dasar motivasi individu dalam berperilaku, termasuk pembentukan perilaku kesehatan. ${ }^{5}$ Penelitian yang dilakukan oleh Farahan menemukan bahwa pengetahuan terbanyak yang dimiliki responden adalah metode kontrasepsi suntik dan sekaligus menjadi pilihan metode $\mathrm{KB}$ terbanyak. Selain itu hanya seperempat dari jumlah responden yang mengetahui jenis kontrasepsi jangka panjang (MKJP) dan efek sampingnya. Penelitian tersebut juga menyatakan bahwa pengetahuan dan pemahaman yang kurang mengenai metode KB merupakan faktor pencetus kurangnya kesadaran penggunaan KB dan keterbatasan responden dalam pemilihan metode ber-KB yang sesuai dengan keadaan tubuh mereka. Hasil penelitian tersebut menyimpulkan bahwa semakin tinggi pengetahuan wanita tentang metode $\mathrm{KB}$, maka akan semakin tinggi kesadaran dan keikutsertaan PUS dalam penggunaan KB. ${ }^{6}$ Oleh karena itu penelitian ini untuk mengetahui gambaran pengetahuan tentang kontrasepsi pada akseptor kontrasepsi wanita di Puskesmas Wilayah Kota Pekanbaru menarik untuk dilakukan, pada akhirnya diharapkan hasil dari penelitian ini dapat dijadikan bahan referensi atau bacaan bagi puskesmas terkait dan juga akseptor kontrasepsi wanita di kota Pekanbaru.

\section{BAHAN DAN METODE}

Penelitian ini menggunakan desain studi deskriptif observasional, dengan rancangan penelitian cross sectional. Penelitian ini dilakukan pada 12 Puskesmas di kota Pekanbaru, dengan responden/sampel akseptor kontrasepsi wanita. Teknik pengambilan sampel dilakukan dengan cara stratified random sampling dengan besar sampel 400 orang. Strata yang digunakan dalam sampling yaitu 12 wilayah kecamatan di Kota Pekanbaru sehingga didapatkan 32-34 responden untuk tiap strata. Pengambilan data melalui wawancara dengan panduan kuesioner mengenai pengetahuan akan metode kontrasepsi. Kuesioner dibuat berdasarkan Medical Eligibility Criteria yang telah melewati uji

validitas dan reliabilitas. ${ }^{7}$ Sebelum pengambilan data, dilakukan informed consent kepada masing-masing responden. Data yang didapatkan akan dianalisis secara statistik deskriptif berupa frekuensi dan distribusi untuk mendeskripsikan 
Susanti, L : Gambaran Pengetahuan Tentang Kontrasepsi...

gambaran pengetahuan akseptor tentang kontrasepsi dan faktor terkait lainnya.

\section{HASIL DAN PEMBAHASAN}

Demografi dan karakteristik responden dapat dilihat pada Tabel 1. Data didapat dari 400 responden yang berasal dari 12 Puskesmas (31-34 orang tiap Puskesmas). Dari hasil penelitian didapatkan gambaran karakteristik usia (Tabel 1, Gambar 1), pendidikan terakhir (Tabel 1, Gambar 2), pekerjaan (Tabel 1, Gambar 3).

Tabel 1 Demografi dan karakteristik responden

\begin{tabular}{|c|c|c|c|c|}
\hline No & $\begin{array}{c}\text { Karakteristik } \\
\text { Demografi }\end{array}$ & Distribusi & Frekuensi & Persentase (\%) \\
\hline \multirow[t]{13}{*}{1} & Kecamatan & Sukajadi & 33 & $8,3 \%$ \\
\hline & & Tampan & 34 & $8,5 \%$ \\
\hline & & Pekanbaru Kota & 32 & $8,0 \%$ \\
\hline & & Marpoyan Damai & 31 & $7,8 \%$ \\
\hline & & Lima Puluh & 32 & $8,0 \%$ \\
\hline & & Tenayan Raya & 34 & $8,5 \%$ \\
\hline & & Senapelan & 34 & $8,5 \%$ \\
\hline & & Payung Sekaki & 34 & $8,5 \%$ \\
\hline & & Rumbai Bukit & 34 & $8,5 \%$ \\
\hline & & Rumbai Pesisir & 34 & $8,5 \%$ \\
\hline & & Bukit Raya & 34 & $8,5 \%$ \\
\hline & & Sail & 34 & $8,5 \%$ \\
\hline & & Total & 400 & $100 \%$ \\
\hline \multirow[t]{5}{*}{2} & Usia & 20-29 tahun & 81 & $20 \%$ \\
\hline & & 30- 39 tahun & 179 & $45 \%$ \\
\hline & & 40-49 tahun & 128 & $32 \%$ \\
\hline & & 50-60 tahun & 12 & $3 \%$ \\
\hline & & Total & 400 & $100 \%$ \\
\hline \multirow[t]{7}{*}{3} & Pendidikan & Tidak sekolah & 2 & $0,5 \%$ \\
\hline & & SD & 38 & $9,5 \%$ \\
\hline & & SMP & 113 & $28,25 \%$ \\
\hline & & SMU & 203 & $50,75 \%$ \\
\hline & & Diploma & 19 & $4,75 \%$ \\
\hline & & Sarjana & 25 & $6,25 \%$ \\
\hline & & Total & 400 & $100 \%$ \\
\hline \multirow[t]{5}{*}{4} & Pekerjaan & Karyawan tetap & 10 & $2 \%$ \\
\hline & & Karyawan tidak tetap & 3 & $1 \%$ \\
\hline & & Wirausaha & 66 & $17 \%$ \\
\hline & & Mengurus rumah tangga & 321 & $80 \%$ \\
\hline & & Total & 400 & $100 \%$ \\
\hline
\end{tabular}


Susanti, L : Gambaran Pengetahuan Tentang Kontrasepsi...

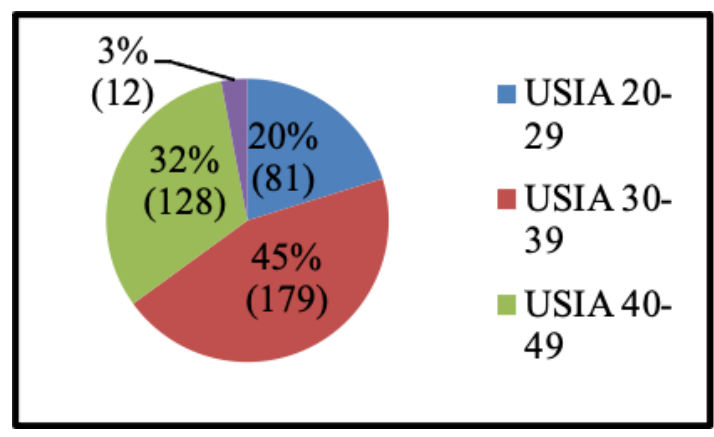

Gambar 1 Karakteristik usia responden.

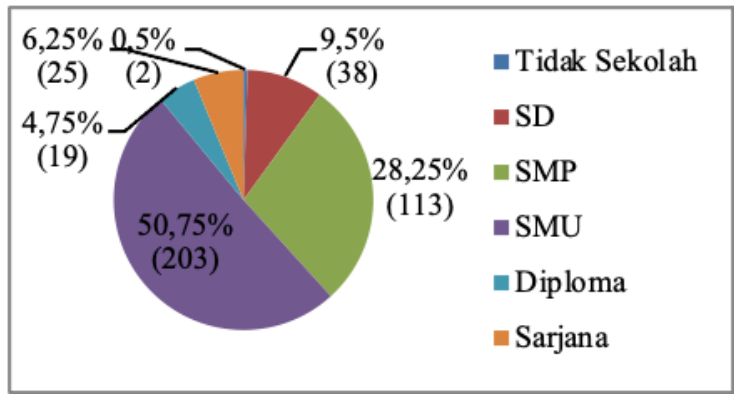

Gambar 2 Karakteristik pendidikan responden.

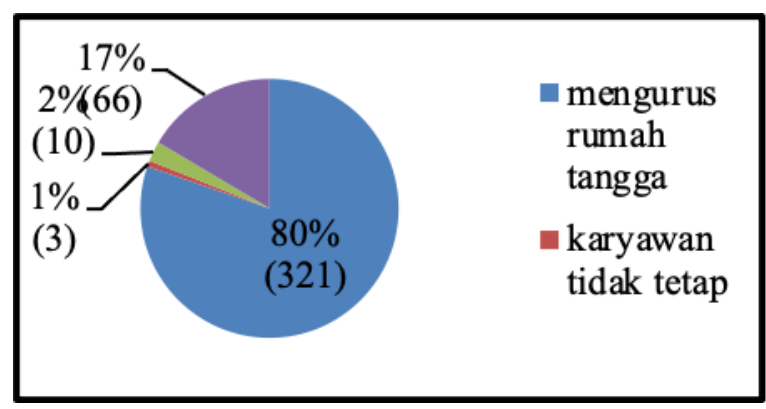

Gambar 3 Karakteristik pekerjaan responden

Dapat dilihat bahwa berdasarkan karakteristik usia, mayoritas responden (45\%) berusia 30-39 tahun. Berdasar pendidikan terakhir, mayoritas responden (50,75\%) berpendidikan akhir SMU. Berdasarkan karakteristik pekerjaan, mayoritas responden $(80 \%)$ bekerja mengurus rumah tangga.
Dari hasil penelitian mengenai pengetahuan tentang kontrasepsi pada akseptor wanita di Kota Pekanbaru (tabel 2), skor pengetahuan terendah ialah 2,90, tertinggi ialah 40,58. Median sama dengan modus yaitu 18.84, dengan skewness 0,257 $<0,5$, dapat disimpulkan data terdistribusi normal. 
Susanti, L : Gambaran Pengetahuan Tentang Kontrasepsi...

Berdasarkan data mengenai (81,8\%) dengan pengetahuan baik, dan 8 tingkatan pengetahuan tentang kontrasepsi pada akseptor wanita di Kota Pekanbaru (Gambar 4) didapatkan mayoritas responden (98\%) memiliki tingkat pengetahuan kurang, 8 responden $(2 \%)$ memliki tingkat pengetahuan cukup dan tidak ada satupun responden yang memiliki tingkat pengetahuan baik mengenai kontrasepsi. Temuan ini berbeda dengan penelitian sebelumnya yang menemukan bahwa dari responden $(18,2 \%)$ dengan pengetahuan kurang. ${ }^{8}$

Dalam hal ini, maknanya hampir seluruh responden pada penelitian ini secara umum tidak mengetahui tentang kontrasepsi meliputi jenis, metode, efektivitas, dan efek samping yang ditimbulkan, meskipun mereka telah menggunakan salah satu ataupun beberapa dari jenis metode kontrasepsi tersebut.

Tabel 2 Deskripsi pengetahuan tentang kontrasepsi

\begin{tabular}{lcr}
\hline & Pengetahuan & \\
\hline $\mathbf{N}$ & Valid & $\mathbf{4 0 0}$ \\
& Missing & $\mathbf{0}$ \\
\hline Mean & & 19.3918 \\
Median & & 18.8400 \\
Mode & & 18.84 \\
Std. Deviation & & 6.58955 \\
Variance & 43.422 \\
Skewness & .257 \\
Std. Error of Skewness & .122 \\
Minimum & 2.90 \\
Maximum & & 40.58 \\
\hline
\end{tabular}

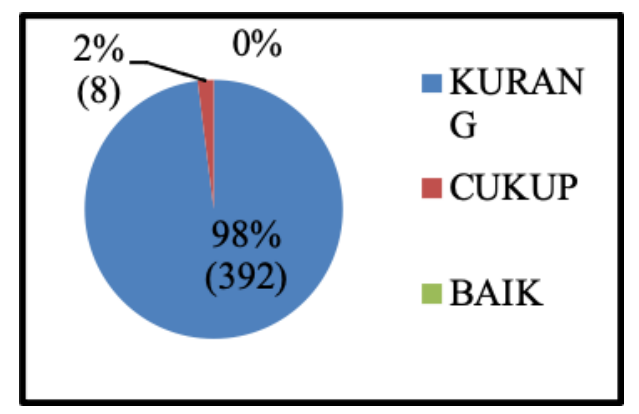

Gambar 4 Gambaran tingkat pengetahuan tentang kontrasepsi pada akseptor kontrasepsi wanita di Kota Pekanbaru.

Pengetahuan dipengaruhi oleh Usia mempengaruhi kemampuan beberapa faktor, salah satunya adalah usia. memahami informasi dan pola berfikir 
Susanti, L : Gambaran Pengetahuan Tentang Kontrasepsi...

seseorang, seiring bertambah usia, maka akan semakin berkembang kemampuan memahami informasi dan pola berfikirnya sehingga pengetahuan yang diperoleh semakin membaik dan bertambahnya pengalaman orang tersebut. ${ }^{9}$ Pada penelitian ini, mayoritas responden berusia 30-39 tahun, namun hasil penelitian menunjukkan hampir keseluruhan responden memiliki tingkat pengetahuan kategori kurang mengenai kontrasepsi.

Teori menyebutkan pengetahuan juga dipengaruhi oleh faktor pendidikan. Sementara itu, dari penelitian ini ditemukan separuh responden berpendidikan menengah $(50,75 \%)$, dan hanya $11 \%$ yang memiliki pendidikan tinggi ( diploma dan sarjana). Perubahan pola pikir tentang macam alat kontrasepsi, keuntungan, kerugian penggunaan, akan memengaruhi seseorang dalam memilih jenis kontrasepsi yang sesuai. Dapat disimpulkan, pendidikan dan pengetahuan yang baik akan membentuk sikap yang positif terhadap kontrasepsi dibandingkan dengan yang kurang baik. ${ }^{10}$

Pekerjaan menjadikan seseorang dapat memperoleh pengalaman dan pengetahuan baik secara langsung maupun tak langsung. ${ }^{9}$ Rendahnya tingkat pengetahuan responden pada penelitian ini mungkin dapat disebabkan karena mayoritas pekerjaan responden adalah kategori mengurus rumah tangga yang menyebabkan terbatasnya pengalaman dan informasi mengenai kontrasepsi yang diterima oleh responden. Pekerjaan menggambarkan aktivitas dan tingkat kesejahteraan ekonomi individu. Hasil penelitian menunjukkan bahwa ibu yang bekerja memiliki tingkat pengetahuan yang lebih baik dari pada ibu yang tidak bekerja.Hal ini disebabkan ibu yang bekerja akan memiliki lebih banyak kesempatan untuk berinteraksi dengan orang lain sehingga mempunyai banyak peluang untuk mendapatkan informasi untuk menambah pengetahuannya. ${ }^{11}$

Dalam pemilihan metode kontrasepsi, pasangan usia subur akan mendapatkan konseling terlebih dahulu dari petugas kesehatan. Konseling membantu pasangan usia subur dalam memilih metode KB yang diinginkan, dengan mempertimbangkan kecocokan dan kriteria kelayakan medis (WHO Medical Eligibility Criteria $(M E C))$, yang dalam praktiknya memakai Alat Bantu Pengambilan Keputusan Ber KB (ABPK). ${ }^{1,5}$ Kenyataannya, 30\% responden tidak melakukan konseling sebelumnya, hal ini dapat dilihat pada gambar 5 . 
Susanti, L : Gambaran Pengetahuan Tentang Kontrasepsi...

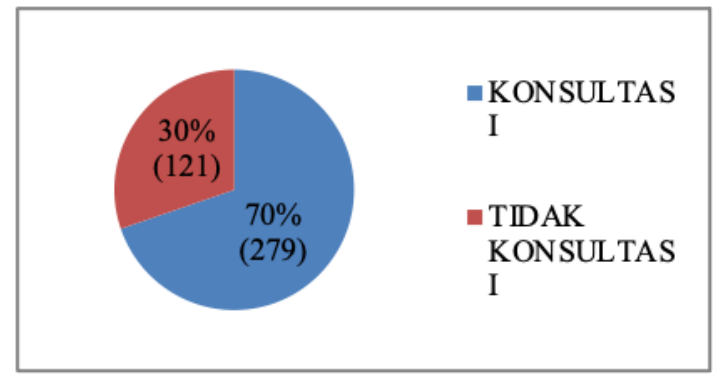

Gambar 5 Karakteristik riwayat konseling.

Beberapa riset menunjukkan ada hubungan positif antara konseling kontrasepsi dengan pengetahuan dan sikap PUS dalam pemilihan metode kontrasepsi, diantaranya Rahardja menemukan bahwa informed choice berhubungan dengan pergantian metode kontrasepsi, artinya dapat menekan angka dropout pengguna kontrasepsi. ${ }^{12}$ Abbas, Emilia, Hartono dalam penelitiannya menemukan konseling saat persalinan kala I memberi pengaruh positif pada penggunaan kontrasepsi pasca persalinan. ${ }^{13}$ Herawati, Wilopo, Hakimi juga menemukan hal yang sama. ${ }^{14}$

Namun, studi oleh Hikmah dan Farida justru menemukan tidak ada pengaruh konseling dalam pemilihan metode kontrasepsi implant. ${ }^{15}$ Hal yang sama juga ditemukan oleh Utami dan Indreswari, tidak ada hubungan konseling $\mathrm{KB}$ dengan pemilihan metode kontrasepsi. ${ }^{16}$ Salah satu sebabnya kemungkinan ketidaklengkapan elemen konseling, seperti yang ditemukan Aini, yaitu kelengkapan elemen konseling berhubungan dengan minat penggunaan kontrasepsi. Selain itu, penelitian Rokhmah menemukan konseling dalam pelayanan $\mathrm{KB}$ belum berjalan dengan baik sebab adanya keterbatasan penguasaan struktur ABPK dan kemampuan tenaga dalam aplikasi ABPK serta belum tercukupinya ruangan yang diperuntukkan khusus untuk konseling KB, sehingga masih banyak tenaga kesehatan yang memberikan konseling kontrasepsi secara lisan tanpa bantuan ABPK. ${ }^{17}$

Dari hasil penelitian mengenai tingkat pengetahuan berdasarkan metode kontrasepsi pada akseptor kontrasepsi wanita di Wilayah Kota Pekanbaru didapatkan bahwa mayoritas responden memiliki tingkat pengetahuan kurang mengenai metode kontrasepsi 384 orang, lendir serviks 375 orang. Hasil penelitian ini sesuai dengan penelitian mengenai pengetahuan dan sikap tentang efek samping dari implan pada perempuan di pusat kesehatan primer, distrik Al-Mukalla, Yaman, yaitu ditemukan mayoritas responden $82,3 \%$ dengan pengetahuan rendah, 15,6\% dengan pengetahuan sedang, dan $2,1 \%$ responden dengan pengetahuan baik tentang implan. ${ }^{18,19}$ Artinya, mayoritas 
Susanti, L : Gambaran Pengetahuan Tentang Kontrasepsi...

pengguna kontrasepsi tidak mengetahui dengan jelas efek samping dan efektivitas metode kontrasepsi. Pada penelitian tentang hubungan pengetahuan dengan sikap istri dalam pemilihan kontrasepsi alamiah metode ovulasi billings (MOB) ditemukan $21(68 \%)$ dari 31 responden dengan pengetahuan kurang, 5 (16\%) responden dengan pengetahuan cukup, dan 5 (16\%) responden dengan pengetahuan baik tentang lendir serviks. ${ }^{20}$ Sebuah penelitian lain tentang pengetahuan akan metode kontrasepsi, menemukan 201 dari 388 $(51,7)$ responden, memiliki pengetahuan kurang tentang suntik. ${ }^{21}$

Rendahnya pengetahuan responden mengenai implan, suntik, lendir serviks pada penelitian ini dapat dikarenakan tingkat pendidikan responden. Sebagian besar responden penelitian ini memiliki tingkat pendidikan SMP dan SMU, yang menjadi sebab keterbatasan informasi yang diterima. Selain itu juga, pengetahuan dipengaruhi oleh latar belakang pekerjaan.

Pekerjaan membuat seseorang dapat memperoleh pengalaman. Responden pada penelitian ini mayoritas memiliki latar belakang pekerjaan mengurus rumah tangga sehingga kemungkinan minim pengalaman yang didapatkan oleh responden mengenai kontrasepsi.

Selanjutnya pada tingkat pengetahuan cukup, metode kontrasepsi tubektomi 185 orang. Hal ini sejalan dengan penelitian serupa tentang metode kontrasepsi tubektomi, yaitu terdapat 46 dari 91 (51) \% responden memiliki pengetahuan cukup tentang kontrasepsi tubektomi. Responden yang memiliki pengetahuan cukup tentang tubektomi pada penelitian, mungkin dapat dikarenakan tindakan konseling di puskesmas. Meski menurut sebuah penelitian tindakan tubektomi harus dilakukan di rumah sakit karena melalui tindakan pembedahan, sehingga konseling tubektomi lebih mumpuni di rumah sakit dibanding Puskesmas. Hal ini mungkin penyebab masih ada $49 \%$ pengetahuan kurang tentang tubektomi ${ }^{22}$.

Responden yang memiliki pengetahuan kategori baik paling tinggi pada metode kontrasepsi kondom berjumlah 60 orang. Penelitian Gosavi dkk. menemukan 891 dari $1008 \quad(88,4 \%)$ responden mengetahui tentang metode kontrasepsi kondom ${ }^{23}$. Didapatkan seluruh responden mengetahui metode kontrasepsi kondom dan 231 dari 259 (89,2\%) responden memiliki pengetahuan baik tentang metode kontrasepsi kondom ${ }^{24}$.

Pengetahuan bisa diperoleh melalui pengindraan terhadap suatu objek atau stimulus, yang dalam hal ini, pengetahuan responden mengenai kondom dapat diperoleh dari media massa yang banyak mengiklankan berbagai produk kondom. 
Susanti, L : Gambaran Pengetahuan Tentang Kontrasepsi...

Seperti dalam penelitian Sweya dkk. 308 dari 401 (78\%) responden mengetahui tentang kondom dari teman sebaya dan televisi menjadi sumber informasi terbanyak mengenai kontrasepsi kondom ${ }^{25}$.

Mayoritas responden dengan pengetahuan rendah mempertegas tidak tercapainya berbagai indikator kinerja pelayanan keluarga berencana. Beberapa diantaranya ialah contraception prevalence rate menurun $0,4 \%$ dibandingkan tahun 2017 hingga mencapai 63,22\%, turunnya unmet ned $0,24 \%$ menjadi $17,91 \%$ pada tahun 2018. Meningkatnya jumlah pasangan usia subur tidak menggunakan KB 0,19\% menjadi $18,82 \%$ pada tahun $2018^{3}$.

Pengetahuan menjadi salah satu faktor utama dalam membentuk tindakan seseorang, yaitu menjadi salah satu dasar dalam pemilihan metode kontrasepsi. Pelayanan kontrasepsi harus menerapkan prinsip pengambilan keputusan berdasarkan informasi (informed decision-making). Adanya peningkatan pengetahuan PUS mengenai KB dan kontrasepsi, dan penerapan informed decision-making, dan pada akhirnya memperbaiki berbagai permasalahan terkait $\mathrm{KB}$ di Indonesia ${ }^{7}$.

\section{KESIMPULAN}

Mengacu pada hasil dan pembahasan tentang gambaran pengetahuan tentang kontrasepsi pada akseptor kontrasepsi wanita di Puskesmas wilayah Kota Pekanbaru didapatkan kesimpulan bahwa sebagian besar akseptor KB memiliki tingkat pengetahuan kategori kurang tentang metode kontrasepsi. Hampir seluruh responden memiliki pengetahuan kategori kurang tentang 11 metode kontrasepsi yaitu IUD, implan, suntik, pil, kondom, pantang berkala, lendir serviks, suhu basal, metode amenorea laktasi, tubektomi, dan vasektomi

\section{KONFLIK KEPENTINGAN}

Penulisan artikel ini tidak terdapat konflik kepentingan.

\section{UCAPAN TERIMA KASIH}

Terimakasih kepada LPPM Universitas Abdurrab dan Yayasan Abdurrab yang telah mendanai penelitian ini.

\section{DAFTAR PUSTAKA}

1. Kementerian Kesehatan Republik Indonesia. Infodatin Pusat Data dan Informasi Kementerian Kesehatan RI Situasi dan Analisis Keluarga Berencana, 2014

2. Kementerian Kesehatan Republik Indonesia. Alat Bantu Pengambilan Keputusan berKB dan Pedoman Bagi Klien dan Penyedia Layanan (edisi enam). Jakarta, 2018. 
Susanti, L : Gambaran Pengetahuan Tentang Kontrasepsi...

3. Kementerian Kesehatan Republik Indonesia. Data Dan Informasi Profil Kesehatan Indonesia, 2018.

4. Kementerian Kesehatan Republik Indonesia. Buletin Jendela Data dan Informasi Kesehatan kementerian Kesehatan RI Situasi Keluarga Berencana Indonesia. Buletin Jendela Data Dan Informasi Kesehatan, 2016: 2, 11-16.

5. Notoatmodjo, Soekidjo. Promosi kesehatan dan Perilaku Kesehatan. Rineka Cipta. Jakarta. 2012

6. Farahan N. Gambaran Tingkat Pengetahuan Penggunaan Alat Kontrasepsi pada Wanita Usia Subur Dan Dukungan Petugas Di Desa Bebandem Kabupaten Karangasem Bali Tahun 2014. E-Jurnal Medika Udayana, 2016;5(4): 1-12.

7. World Health Organization. Medical Eligibility Criteria for Contraceptive Use $5^{\text {th }}$ Edition, 2015.

8. Bakri Z, Kundre R, Bidjuni H. FaktorFaktor yang Berhubungan dengan Pemilihan Metode Kontrasepsi pada Wanita Usia Subur di Wilayah Kerja Puskesma Ronatana Weru. e-journal Keperawatan (e-Kp), 2019; 7(1): 1-10.

9. Megawati T, Febi K, Adisty R. Hubungan Antara Faktor-faktor yang Mempengaruhi Penggunaan KB dengan Pengetahuan tentang $\mathrm{KB}$ di
Wilayah Kerja Puskesmas Kapitu Kecamatan Amurang Barat. Pharmacon Jurnal Ilmiah Farmasi, 2015; 4(4): 312-319.

10. Dewi, Sri Kesuma. Faktor-Faktor yang Mempengaruhi Penggunaan Kontrasepsi Suntik Pada Akseptor KB di Puskesmas Bungoro Kabupaten Pangkep. Jurnal Ilmiah Kesehatan Diagnosis, 2014; 3(6): 7-13.

11. Sulistyawati, A. Pelayanan Keluarga Berencana. Jakarta: Salemba Medika. 2011

12. Rahardja, Mugia B. Kualitas Pelayanan Keluarga Berencana dan Penggantian Kontrasepsi di Indonesia. Kesmas National Public Health Journal, 2011; 6(3):140-144

13. Abbas M., Hadijono S, Emilia O, Hartono E. Pengaruh Konseling Saat Persalinan Terhadap Kepesertaan Keluarga Berencana Pasca Salin di Kabupaten Kolaka. Jurnal Kesehatan Reproduksi, 2017; 4(2): 127-134.

14. Herawati D, Wilopo, SA, Hakimi M. Konseling Ibu Hamil dan Penggunaan Kontrasepsi Pasca Persalinan. Berita Kedokteran Masyarakat. 2018; 34 (11): 411-415. ISSN 2614-8412.

15. Hikmah, Farida S.I. Pengaruh Konseling Menggunakan Alat Bantu 
Susanti, L : Gambaran Pengetahuan Tentang Kontrasepsi...

Pengambilan Keputusan (ABPK)

Terhadap Pemilihan Kontrasepsi Implan. Jurnal JKFT, 2019; 4(1): 7-13

16. Utami F, Indreswari S.A. Konseling Pemilihan Alat Kontrasepsi pada Wanita Pasangan Usia Subur di Puskesmas Mangkang Semarang. Visikes Jurnal Kesehatan Masyarakat, 2013; 12 (1).

17. Rokhmah, Jamiatu. Evaluasi Penggunaan Alat Bantu Pengambilan Keputusan (ABPK) dalam Pelayanan Keluarga Berencana oleh Bidan Puskesmas di Kota Cirebon [Master Thesis Fakultas Kesehatan Masyarakat Program Magister Ilmu Kesehatan Masyarakat Konsentrasi Administrasi dan Kebijakan Kesehatan Minat Manajemen Kesehatan Ibu dan Anak Universitas Diponegoro] . Semarang: Universitas Diponegoro; 2014.

18. Purwandari A, Tombokan S. Analisis Faktor-Faktor yang Berhubungan dengan Pengetahuan Akseptor KB dalam Pemilihan Alat Kontrasepsi Implant di Puskesmas Tuminting Kota Manado. Prosiding Seminar Nasional Tahun 2017, 2017; 415-423. ISBN 2549-0931

19. Banafa N. S, Al-Hanshi A. S., Almualm Y., Alkathiri M. O. Knowledge And Attitude About Side Effect Of Implanon (Implan) Among
Women Attend Primary Health Center

- Al-Mukalla District, Yemen. Acta Scientific Medical Sciences, 2017;(1); $32-37$

20. Putri E, Limoy M. Hubungan Pengetahuan dengan Sikap Istri Dalam Pemilihan Kontrasepsi Alamiah Metode Ovulasi Billings (MOB). Jurnal Kebidanan, 2017; 7(1): 14-19.

21. Amru D E, Hubungan Tingkat Pengetahuan, Sikap dan Keterjangkauan Jarak Pelayanan Kesehatan Terhadap Kejadian Drop Out Alat Kontrasepsi Suntik Pada Pasangan Usia Subur (PUS) Di Wilayah Kerja Puskesmas Sekupang Kota Batam. Jurnal Bidan Komunitas, 2017; II(2):117-125.

22. Amalia L. Metode Kontrasepsi Tubektomi Menurut Pengetahuan Pasangan Usia Subur. Jurnal Mitra Kesehatan, 2015; 2(1):76-85.

23. Nsubuga H, Sekandi J. N, Sempeera H, Makumbi F. E. Contraceptive Use, Knowledge, Attitude, Perceptions And Sexual Behavior Among Female University Students In Uganda: A Cross-Sectional Survey. BioMed Central Women's Health, 2016; 16(6) :1-11.

24. Gosavi A , Ma Y, Wong H, Singh K. Knowledge And Factors Determining Choice Of Contraception Among 
Susanti, L : Gambaran Pengetahuan Tentang Kontrasepsi...

Singaporean Women. Singapore

Medical Journal, 2016; 57(11):610 615.

25. Sweya M. N, Msuya S. E, Mahande M. J, Manongi R. Contraceptive Knowledge, Sexual Behavior, And Factors Associated With Contraceptive Use Among Female Undergraduate University Students In Kilimanjaro Region In Tanzania. Adolescent Health, Medical And Therapeutics, 2016;7: 109-115. 